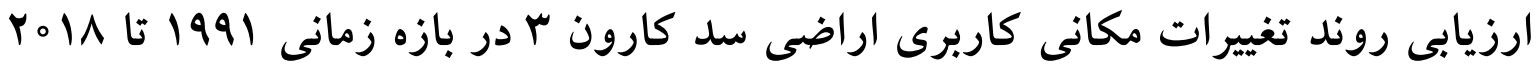

مهدى يزوهش "، هنغامه شكوهيده' و زهرا حيدرى قهفرخى

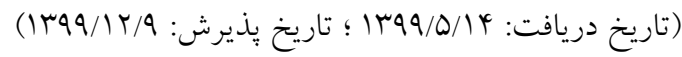

\begin{abstract}
جكيده

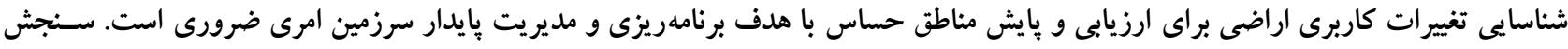

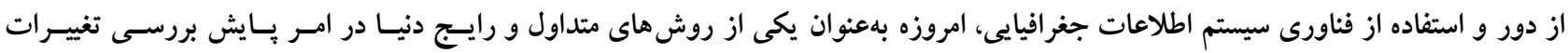

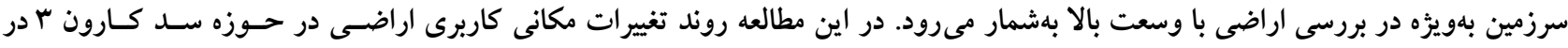

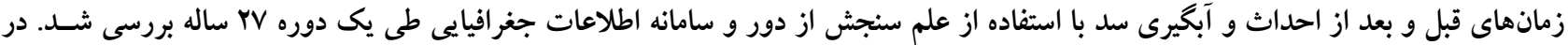

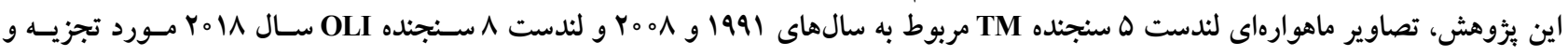

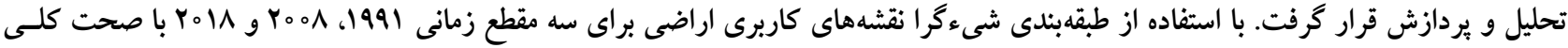

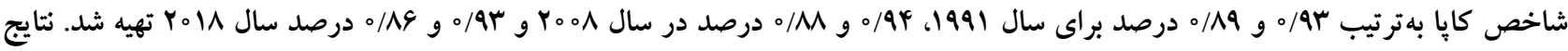

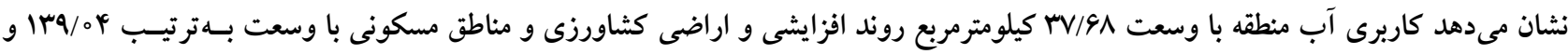

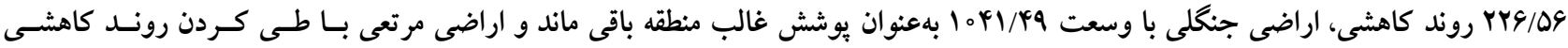

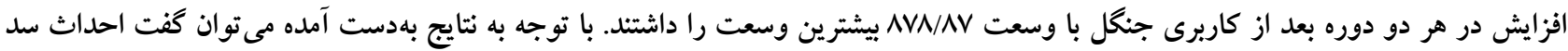

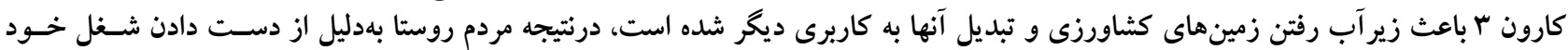

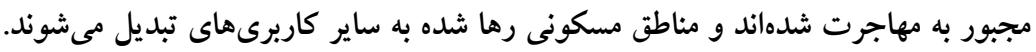

وازههاى كليدى: سد كارون r، تصاوير ماهوارهاى، طبقهبندى شىءرا، تغييرات كاربرى اراضى.

ا. گروه مهندسى حفاظت آب و خاك، دانشكده منابع طبيعى و علوم زمين دانشخاه شهركرد r. گروه مرتعدارى، دانشكده منابع طبيعى و علوم زمين دانشگاه شهركرد * : مسئول مكاتبات: يُت الكترونيكى: drpajoohesh@gmail.com 
است (Y) و TV TV). در سالهاى اخير استفاده از روشهـاى نـوين ازجمله طبقهبندى شئگرا بهشدت در حال افزايش اسـت (س، ه،

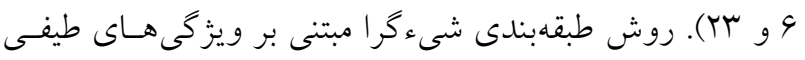

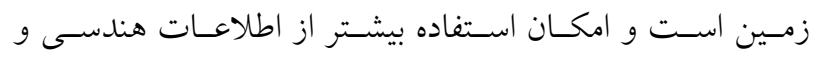
ساختارى را فراهم مى كند (YN). در اين روش اسـاس تجزيسه و

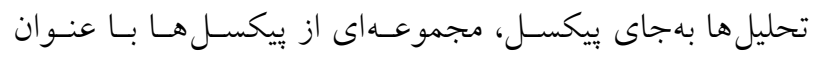
يديدههاى تصويرى است كه محدوديتهــاى روش طبقـهبنــى مبتنى بر بيكسل را براى بررسى تصاوير داراى قـدرت تفكيـك مكانى بـالا را برطـرف سـاخته اسـت (YY). تـاكنون، مطالعـات بسيارى در دنيا به بررسى و تحليـل تغييـرات ناشسى از احـــاث

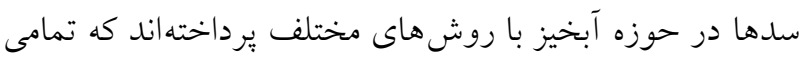
اين مطالعـات اسـتراتزى هــاى مـؤثر و مناسـبى بــراى مـــيريت حوزههاى آبخيز سراسر دنيا ارائه مىكنند. مرور سوابق مطالعاتى حاكى از اين است كه در دهههاى اخير، تغييرات سريع كـاربرى اراضى در اثر سدسازى از جنشخل به كشـاورزى و نيـز مرتـع بــه

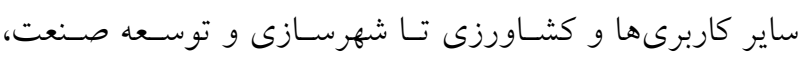

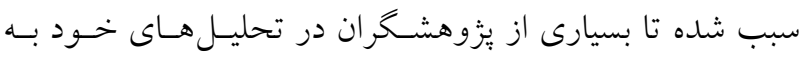
تبيين دقيق اثر تغييرات كاربرى اراضى روى سيستم حوزه آبخيز بيردازنـــ (Y) (Y). هاديــان و همكــاران (11) از قابليـت تصــاوير ماهواره لندست در طبقهبنـدى كـاربرىهـا و ويوشـش سـرزمين بهمنظور بررسى تأثير احداث سد حنـا در اصـفهان بـر تغييـرات كاربرى و يوشش اراضى استفاده كردند. بهدليل احسـاث ســ در

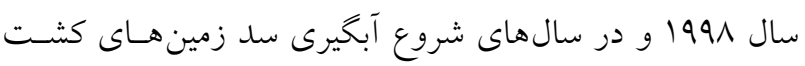

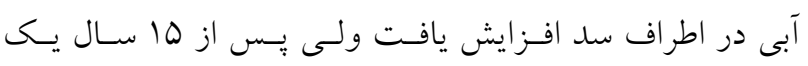
كاهش شديد در سطح اين اراضى مشاهده شد. يرور و همكاران (YT) از قابليت تصاوير ماهوارهاى لندست براى پايش تغييـرات ناشى از احداث سد شيرين دره بر بوشـش و كـاربرى اراضسى

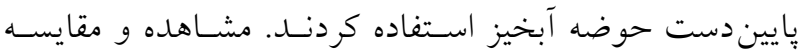
نقشههاى تهيه شده نشان مىدهد در بازه مطالعاتى، كاربرى باغ و كشاورزى كاهش داشته و بـهـ زراعـت ديــم تغييـر كـاربرى

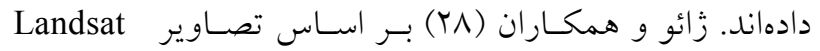

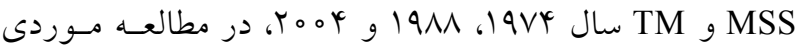

مقدمه

رشد فزاينده جمعيت در طى دهـهـهـاى اخير و بــهـــع آن نياز به مواد غذايى و آب، بشر را بر آن داشته تا زمـــينهـــاى بيشترى را براى كشت و زرع تحــت تسـلط خـود درآورد ( (1). بـالطبع ايسن زمينها نياز مبرمى به آب دارند كه اين امر بيشتر بهوسـيله كتتـرل

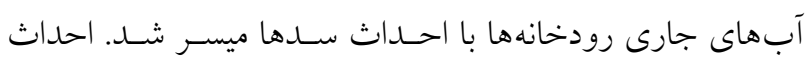

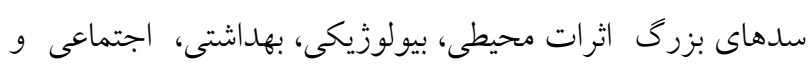
اقتصادى مهمى را در محيط اطراف خود بهوجود مى آورند؛ اما در اين ميان اهميت كاربرى اراضى بهدليل نقـش مـؤثر انسـان در آن مهئ نسبت به ديخر عوامل تغيير كاربرى اراضى بيشتر است؛ بهعبـارت ديخر، نوع بهرهبردارى از اراضى عامل بسيار مهمى در فرسايش و توليد رسوب حوضههاى آبخيـز بـهـــمار مسىرود (ب). تغييـرات كاربرى اراضى يكى از عوامل مهم در تغيير جريان هيـدرولوزيك، فرسايش حوزه و انهام تنوع زيستى است؛ بنـابراين بـا اطـلاع از روند اين تغييرات مىتوان در راستاى هدايت اكوسيستم بلهسمت تعادل قدم برداشت. داشـتن آمـار و اطلاعــات بـه هنخــام، لازمـهـ مديريت صحيح عرصههاى طبيعى است. در اين ميـان اسـتفاده از

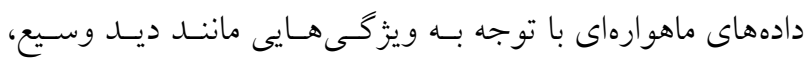

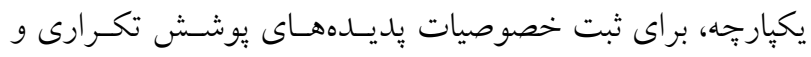

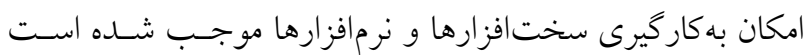
كه در سالهاى اخير، با استقبال خاصسى روبـهرو شـود. از طرفى استفاده از روش هاى نقشهبــردارى زمينـى بـهدليـل هزينـه بـالا و زمانبر بودن آن براى بررسى رونـــ تغييـرات بوشـش اراضسى در اكثر اوقات غيرقابل انجـام اسـت. طبقـهبنــى كـاربرى اراضسى و

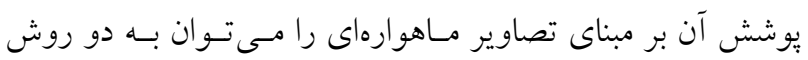
كلى انجام داد. اولين رويكرد بر مبنـاى بيكسل هــا هسـت كـه از مـــتهـا قبـل بــراى دادههـاى ســجش از دورى مـورد اسـتفاده محققين سنجش از دور بـوده اسـت و بــراى تصـاوير بــا قـدرت

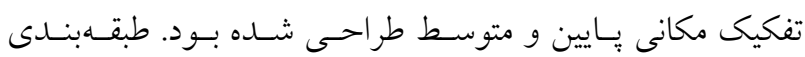
حـــاكثر احتمـال (Maximum Likelihood Classifier) يكـى فنهاى طبقهبندى مبتنى بر بيكسل است كـه بـهــور كسـتردهاى براى استخراج اطلاعات موضوعى از دهه م191 استفاده مى شده 


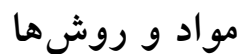

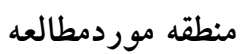

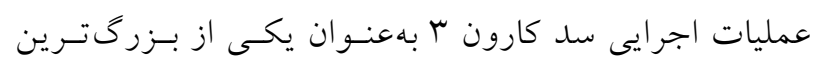

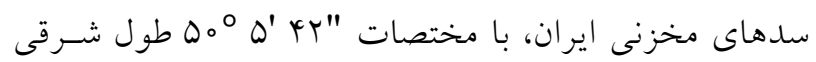

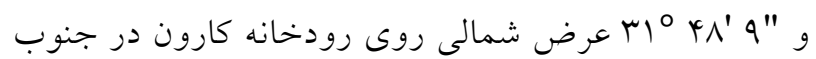

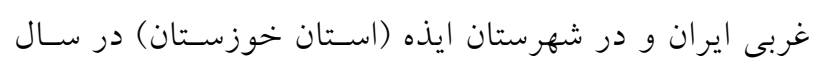

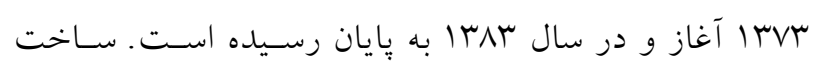

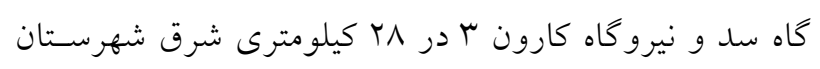

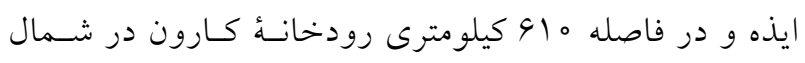

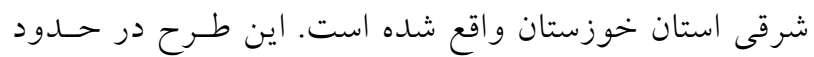

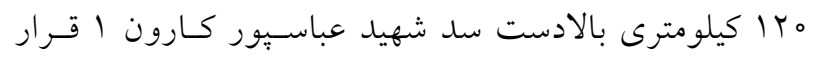

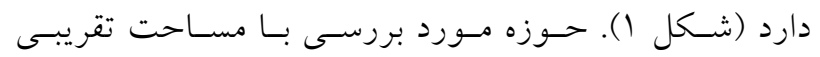

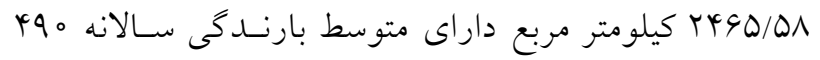

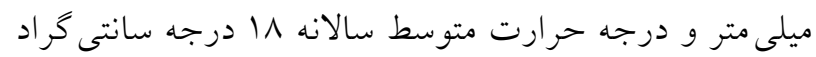

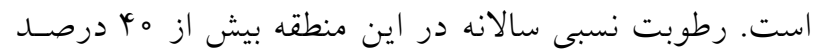

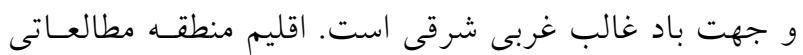

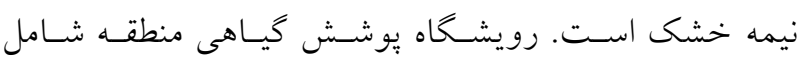

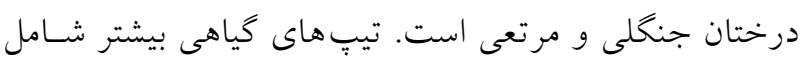

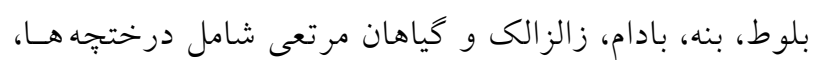

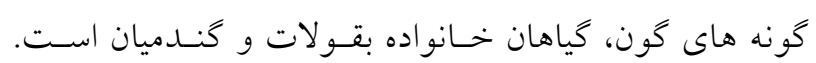

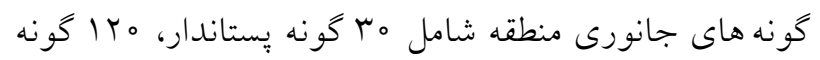

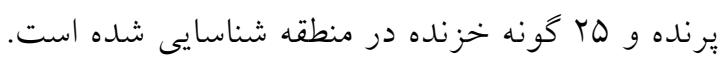

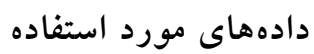
"،س از انجـام مطالعـات ميـدانى و كتابخـانـهاى، اطلاعـات،

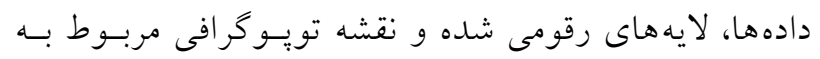

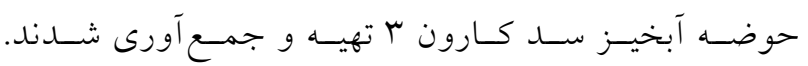

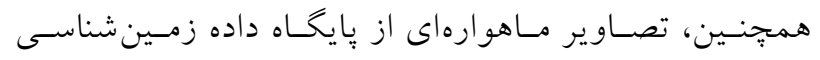

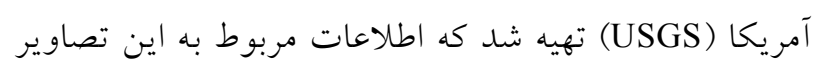

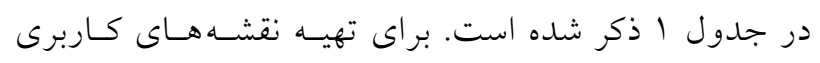

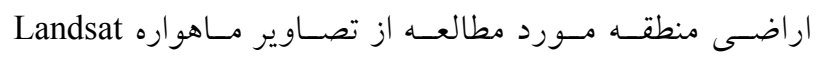

سد مانوان در امتداد رودخانه لانسانگ (مكونگ) تعيين فاصله

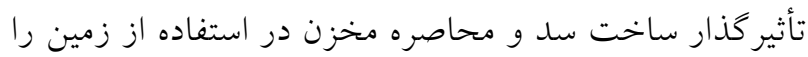

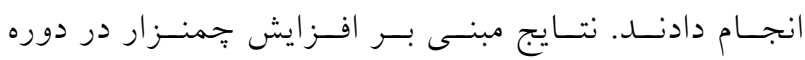

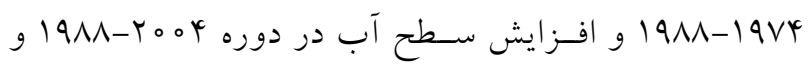
كاهش سرزمين جنخلى در هر دو دوره بود. بات و همكاران

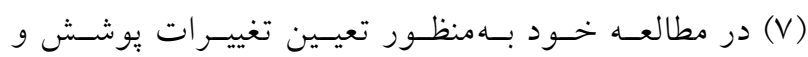

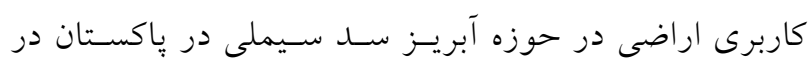

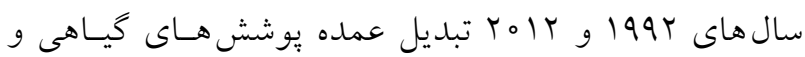

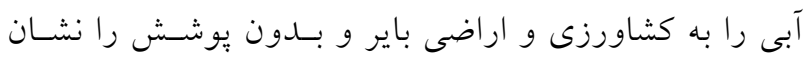

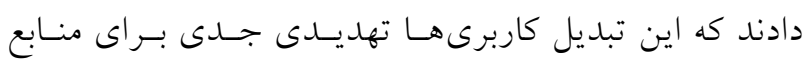

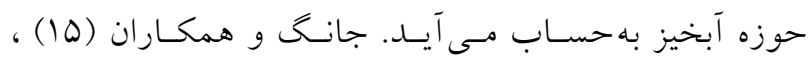

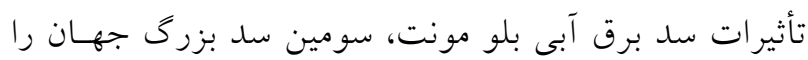

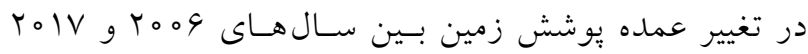

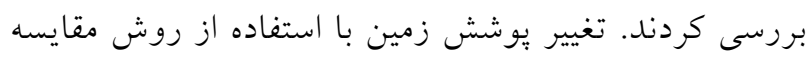

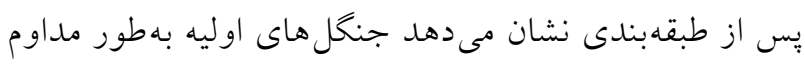

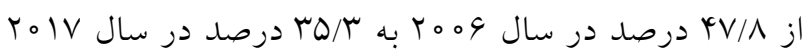

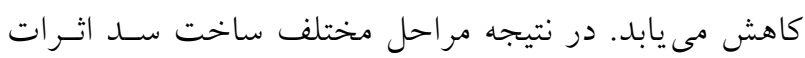

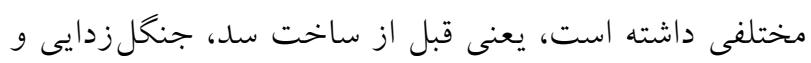

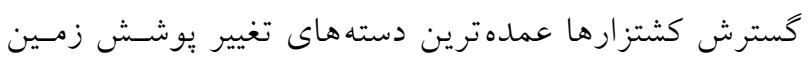

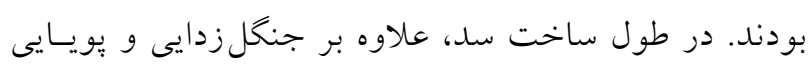

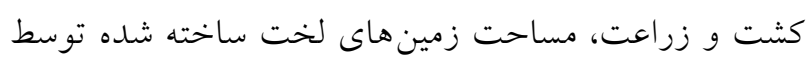

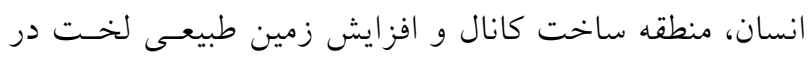

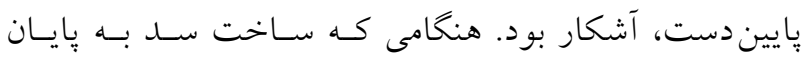

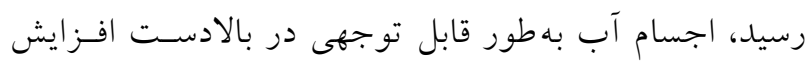
يافته و در باييندست كاهش مى يابد. بابد.

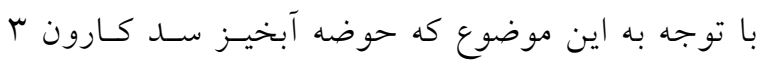

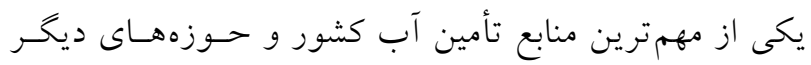

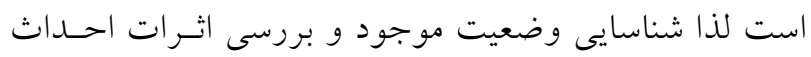

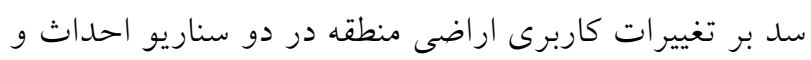
عدم احداث سد، مىتواند به مديريت بهتر محسيط زيست و و همجنين كاهش محدوديتها و استفاده از ظرفيتهاى حوزه

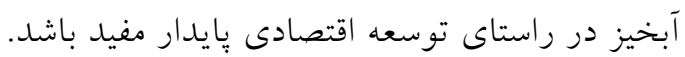




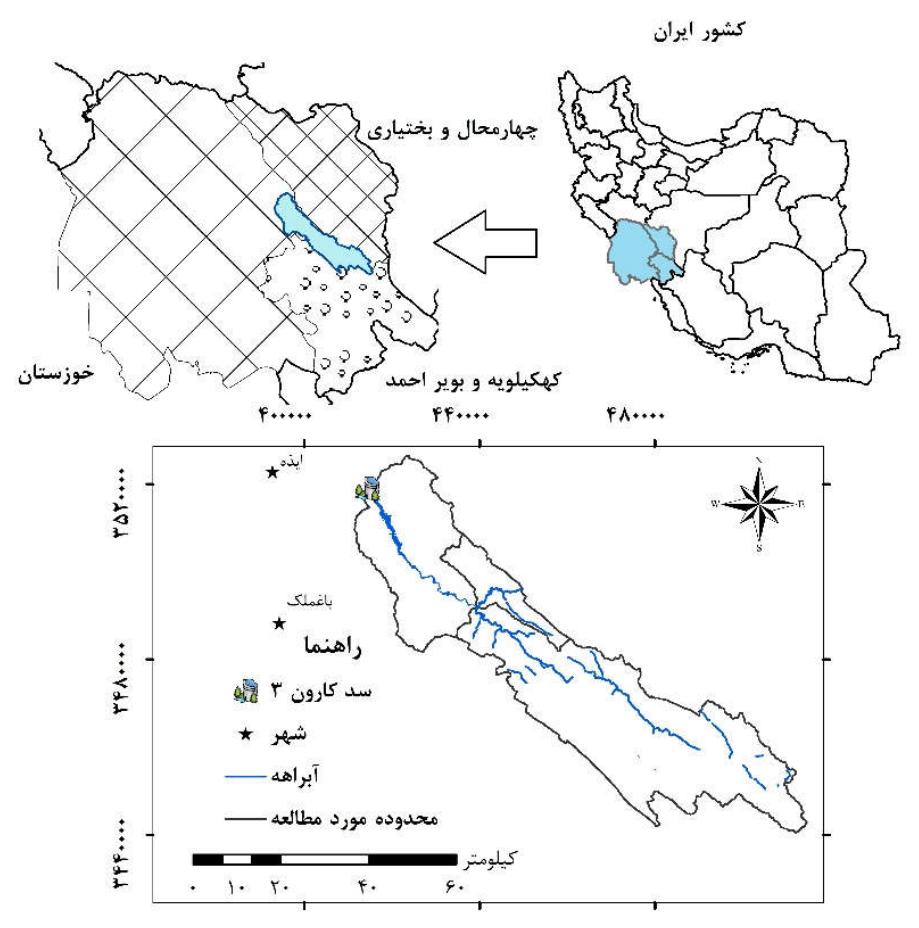

شكل 1. موقعيت استان و حوضه آبخيز سد كارون ب

جدول ا. خصوصيات تصاوير ماهوارهاى مورد استفاده در تحقيق

\begin{tabular}{|c|c|c|c|c|c|}
\hline باندها & بيَكسل هازها & زمان تصويربردارى & زمان تصويربردارى & سنجنده & ماهو اره \\
\hline V باند V & باند متر بهجز & IrVO/Or/rG & 4/19 زوئن/1991 & $\mathrm{TM}$ & لندست ه \\
\hline V باند V & 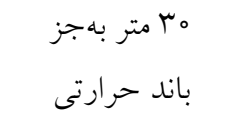 & $\mid r \wedge V / \circ \% / l \circ$ & 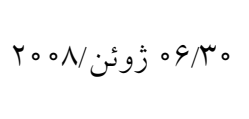 & $\mathrm{TM}$ & لندست ه \\
\hline ا 11 باند & 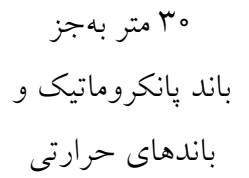 & $\mid r q V / 04 / 0 q$ & 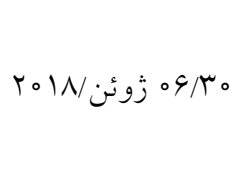 & OLI & لندست \\
\hline
\end{tabular}

\section{روش انجام تحقيق}

تصحيحات هندسى و راديومتريكى

در اين تحقيق با توجه به اينكه تصاوير ماهوارهاى دانلود شده از

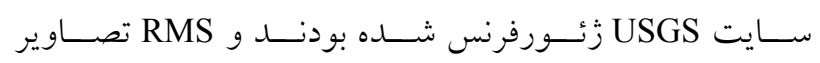
ماهوارهاى از نصف بيكسل سـايز تصـاوير كمتـر بـود تصسحيح هندسى انجام نشد (19). خطاهاى راديومتريك معمولاً به دلايل
سـنجنده Thematic Mapper) TM بـراى سـالهـاى 1991 و

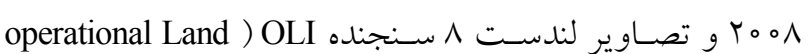
براى سال Imager Google Earth و Terrset18.6، ENVI 5.3، ARCGIS 10.3 براى بررسى، تجزيه و تحليل تصاوير و تهيه نقشههاى كـاربرى اراضى استفاده شد. 
جدول r. بֶارامترهاى تصحيح اتمسفريك FLAASH

\begin{tabular}{|c|c|}
\hline 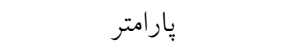 & مدل انتخابى \\
\hline مدل اتمسفريك & mid latitude summer \\
\hline مدل آئروسل & Rural \\
\hline ديد اوليه & 40 \\
\hline بازيابى آثروسل & 2band K-T \\
\hline Water column multiplier & $1: 00$ \\
\hline
\end{tabular}

\section{تهيه نقشههاى كاربرى اراضى}

يس از انجام تصسحيحات راديـومتريكى و اتمسـفريك روى تصاوير خام، اقـدام بـهـ ايجـاد تركيـب بانـدى كـاذب بــراى تشخيص بهتر عوارض و يديدههاى سـطح زمسين بـهـمنظـور طبقهبندى تصاوير ماهوارهاى شد و از تركيب بانـدى كـاذب rrא براى تصاوير ماهواره لندست ه سنجنده TM و تركيـب

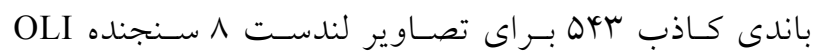

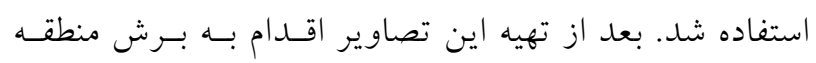
مورد مطالعه از روى تصاوير رنكى كاذب بهوجود آمسـه بــر اساس مرز حوزه آبخيز شد، در اين روند هر يك از تصـاوير در سيستم مختصات UTM -WGS84 زئسورفرنس شــند و سيس محدوده داخلى مرز حوضه به كمك لايسه وكتـورى آن در هر تصوير برش داده شد و subset بهدسـت آمسـه از هـر

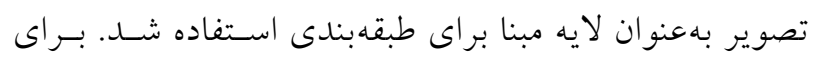
دستيابى به نقشه كاربرى اراضى صحيح از تصاوير ماهوارهاى بايد بتوانيم در ابتدا كاربرىهاى موجود در منطقه را بهخوبى

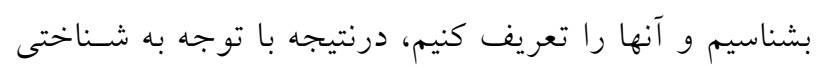

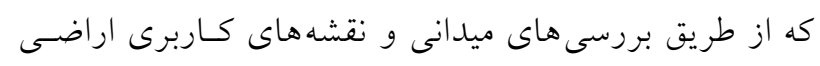
بيشين و همجِنين نرمافزار Google earth از منطقه بهدسـت

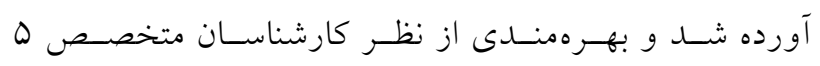
كاربرى مناطق مسكونى، اراضى كشاورزى، مرتـع، جنخـل و و

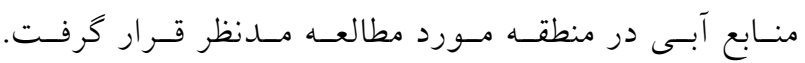
مشخصات آنها در جدول ب ارائه شده است.
اختلاف در شـرايط اتمسـفرى (جـــب و بخـش)، اخـتلاف در زاويه تابش و يا خطاهاى ناشى از سنجندهها ايجاد مىشوند لـذا تصحيح راديومتريكى تصـاوير لندسـت هو 1 از طريـق تبـديل اعداد رقومى به راديانس در بانــهاى حرارتسى و تبــيل اعـداد رقومى به انعكـاس در بانـدهاى انعكاسـى در محسيط نــرمافـزار ENVI

تصحيحات اتمسفرى

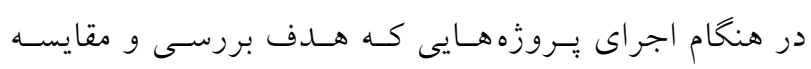
تصـاوير مـاهوارهاى در جنـــ زمـان اسـت انجــام تصـحيح اتمسفريك بسيار با ارزش اسـت. روشهــاى متنـوعى بـراى جبران اثرات اتمسفر بر تصوير ابــاع شـدهانــ كـه در ايسن تحقيق از روش FLAASH در نرمافزار ENVI استفاده شــ. روش FLAASH، اثـــات جــوى و اثــرات مجــاور در طـول موجهاى SWIR و VNIR را تصحيح مى كند. تصوير ورودى برنامه FLAASH بايد تصوير انرزى تابشى (راديانس) باشــ كه واسنجى راديـومتريكى روى آن صـورت كرفتسه و داراى فرمست BIL و BIP باشــند. در تصسحيح FLAASH نسـخه انتخاب شده مطـابق بـا اسـتانداردهاى منطقـه مورد مطالعه براى تصحيح خطا در يارامترهاى خط آب بـود

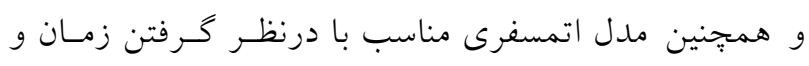
شرايط تصويربردارى براى برآورد ميز ان بخار آب موجــود در جو براى تصاوير فاقد باند انتخاب شد، يارامترهاى تصسحيح اتمسفريك FLAASH در جدول r ارائه شده است. 


\begin{tabular}{|c|c|c|}
\hline توضيحات & 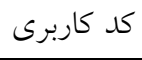 & نوع يوشش و كاربرى اراضى \\
\hline مخزن سد با عمق زياد - رودخانهها - تالاب & 1 & 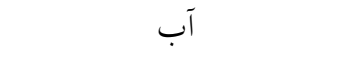 \\
\hline جنگل كم تراكم و متراكم & $r$ & جنظل \\
\hline انواع گونههاى گياهى - اراضى باير و آيش & $r$ & مرتع \\
\hline كشت آبى و ديم - باغ & r & 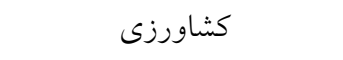 \\
\hline تأسيسات و مناطق مسكونى & 0 & مناطق صنعتى و مسكونى \\
\hline
\end{tabular}

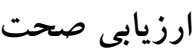

صحت طبقهبندى بيانكر سطح اعتماد بـه نقشـه اسـتخراج شــه

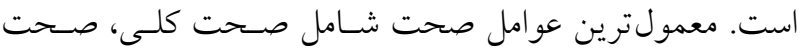

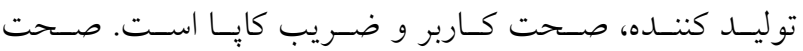
طبقهبندى نقشههاى كاربرى اراضى تهيه شـــه بـا اسـتفاده از دو شاخص صحت كلى و شاخص كايا بررسى شـــ. ضـريب كايـا نشاندهنده توافق صحت كلى با حالت موجود در طبيعت اسـت

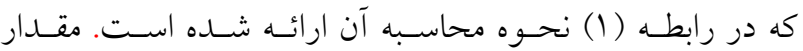

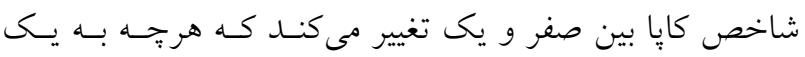

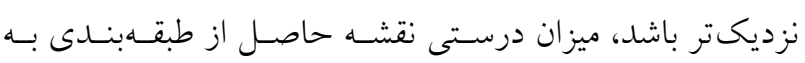
واقعيت نزديكتر است.

Kappa $=\frac{\mathrm{po}_{\mathrm{o}}-\mathrm{pc}_{\mathrm{c}}}{1-\mathrm{pc}_{\mathrm{c}}} * 100$

در اين رابطه؛ Po: صحت مشاهده شده، Pc: توافق مورد انتظار

\section{نتايج}

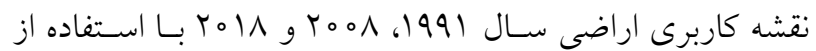

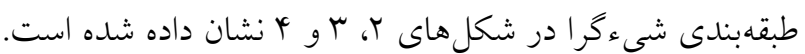

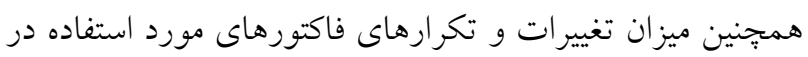

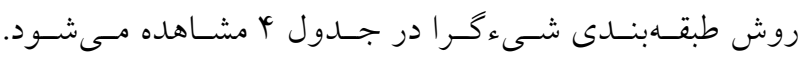

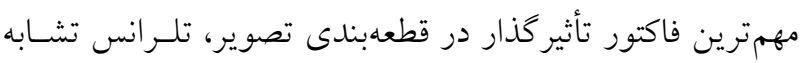

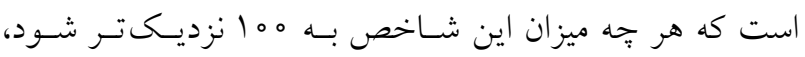

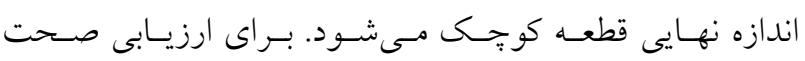

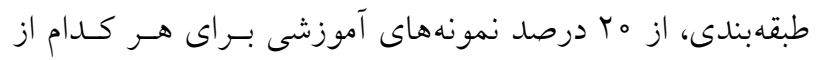
كاربرىها كه بهصورت تصادفى از سـطح منطقـه مـورد مطالعـه
طبقهبندى شىء طبقهبندى شىءر ا فرايندى است كه طبقات يوشش اراضى

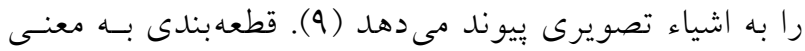
كروهى از ييكسل هاى همسايه در داخل يكى ناحيه است كـهـ شباهت (نظير ارزش عددى و بافت و غيره) مهم ترين معيسار

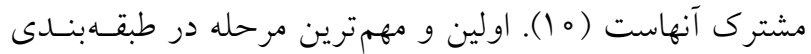

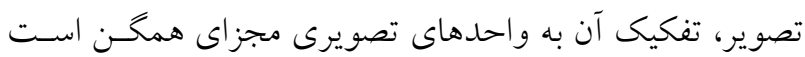
(r) (1). در نرمافزار TerrSet تصاوير بر اساس جهار فاكتور بهناى ينجــره (Window width)، تحمــل تشــابه ( Similarity

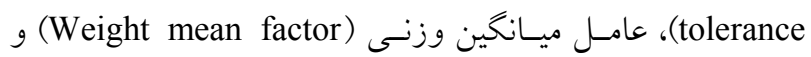
فاكتور واريانس وزنسى (Weight variance factor) بـه قطعـات

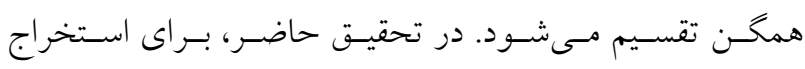

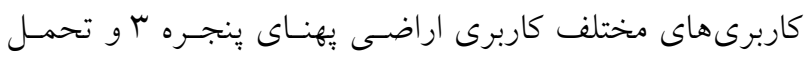

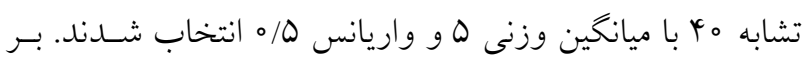
مبناى تصاوير قطعهبندى شده، معرفى امضاهاى طيفى، با استفاده از تصوير كاذب و بر اساس نمونههاى تعليمى انتخاب شــده در

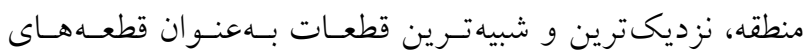

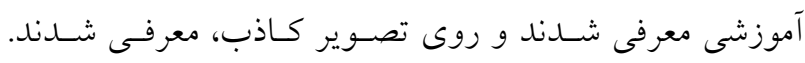

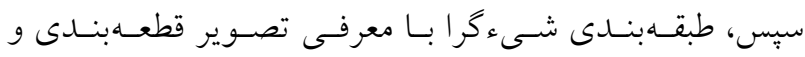
خروجى طبقهبندى حداكثر احتمال در خوارزميـى (Segclass)

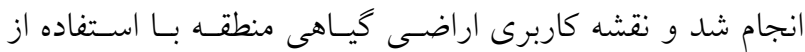

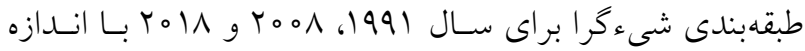
كرنل ب و دامنه شباهت مب ساخته شد. 

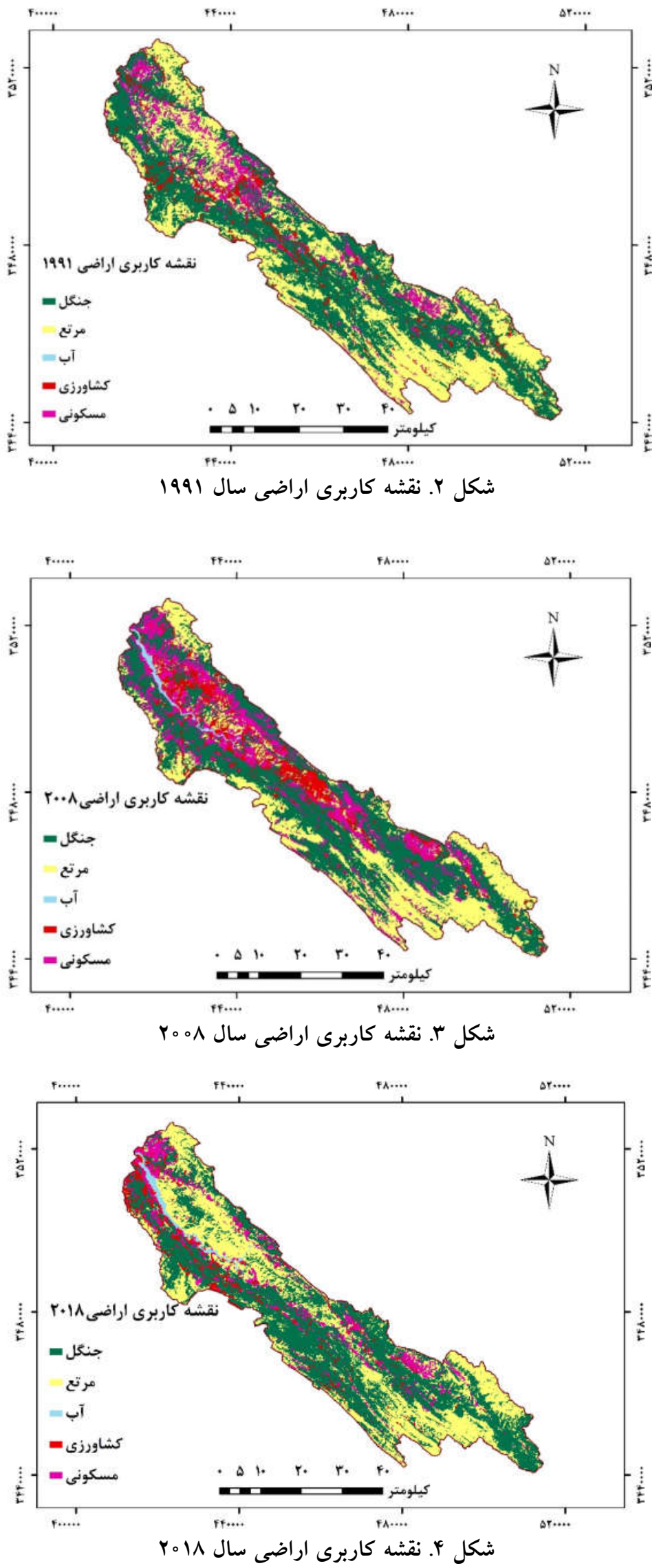


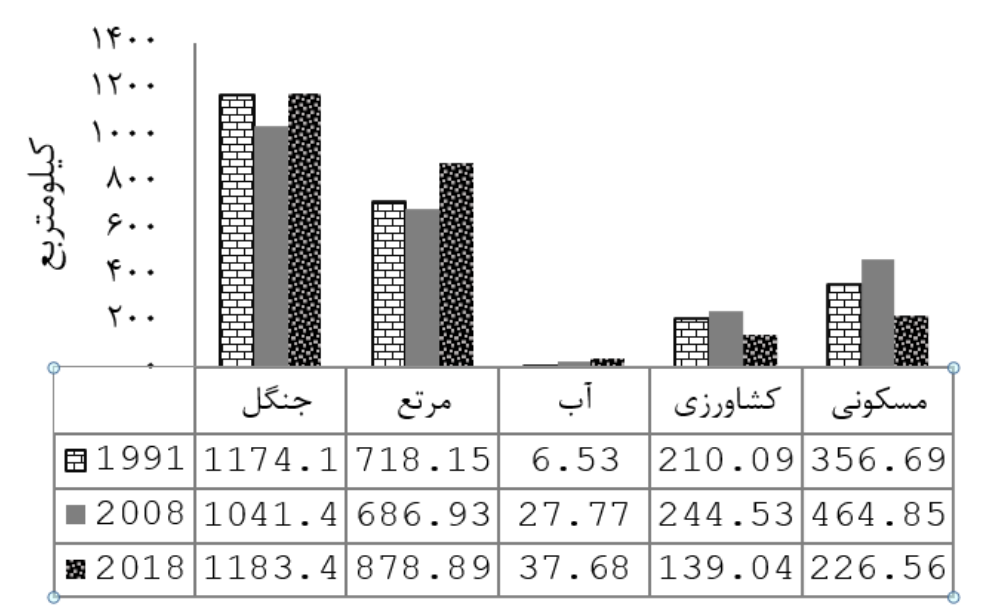

شكل ه. نتايج مربوط به ميزان تغييرات رخداده در هر كاربرى در سالهاى موردمطالعه

جدول f. فاكتورهاى قطعبندى مورد آزمون در روش شىءگرا و بهترين مقدار آن براى منطقه مورد مطالعه

\begin{tabular}{|c|c|c|c|}
\hline دامنه تغييرات & بهترين حالت & ت ت ت تكرار & فاكتور \\
\hline $0-10$ & r & ا تا 9 & يُهناى ينجره \\
\hline $0-100$ & $\psi_{0}$ & $100-\omega \circ-4 \circ-1 \circ$ & تلر انس تشابه \\
\hline $0-10$ & 0 & ا تا و & فاكتور ميانگين وزنى \\
\hline $0-1$ & $\circ / 0$ & $\circ / 1,0 / 9 ، 0 / 0 ، 0 / 1$ & فاكتور واريانس وزنى \\
\hline
\end{tabular}

اين مقدار كاهش ييدا كرد و به ب19/9 كيلومتر مربع رسيد ولى

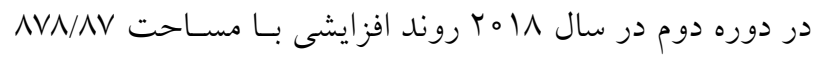
كيلومترمربع داشته است. كـاربرى جنخـل در كـل دوره مطالعـه

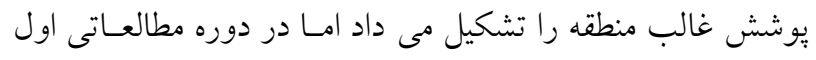

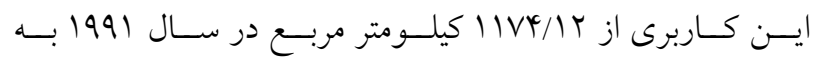

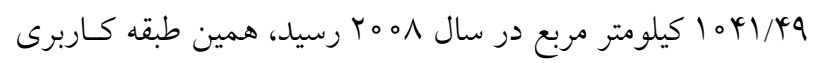

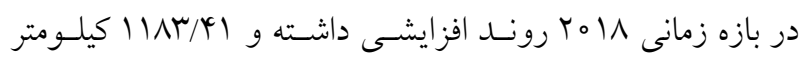

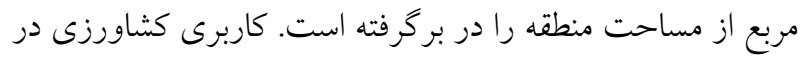

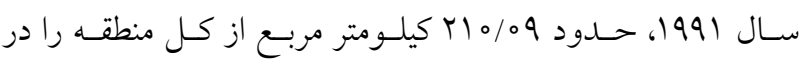

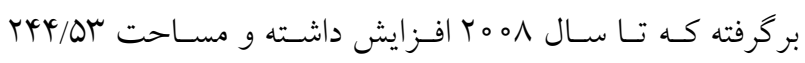

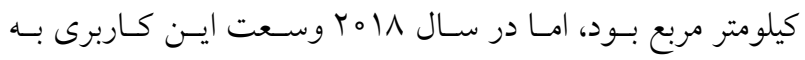

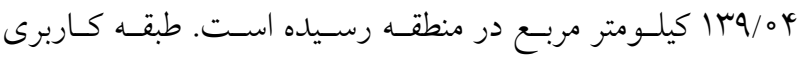

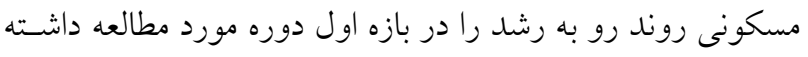

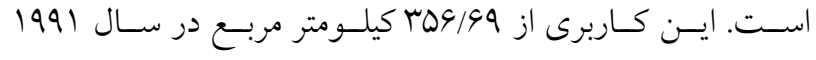

جمع آورى شد، استفاده شد و پـس از بيـادهسـازى نمونـهـهـاى

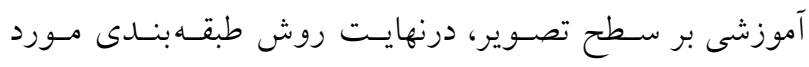

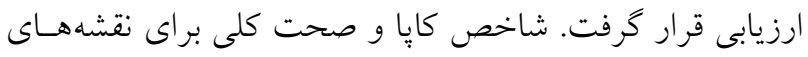

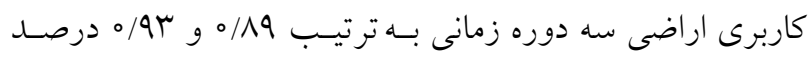

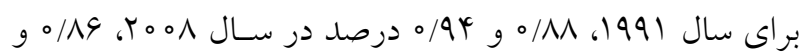

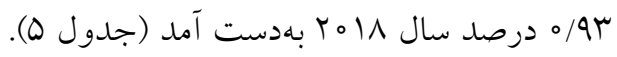

$$
\text { روند تغييرات كاربرى اراضى }
$$

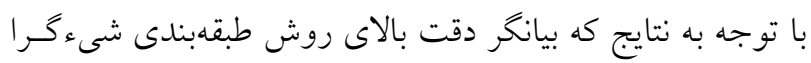

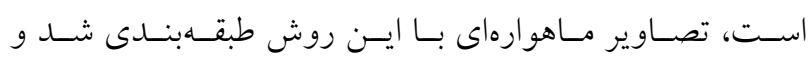

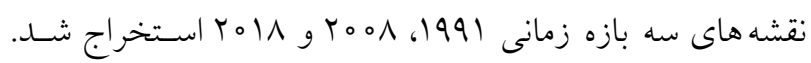

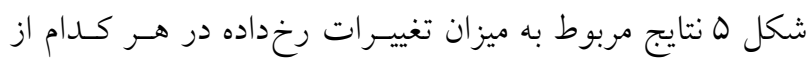

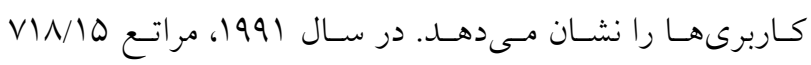

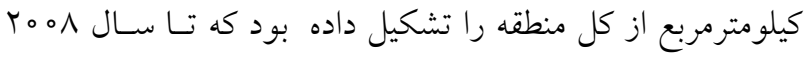


جدول ه. صحت طبقهبندى نقشههاى كاربرى اراضى از سال 1991 تا Yo11

\begin{tabular}{|c|c|c|}
\hline $\begin{array}{l}\text { شاخص كايا } \\
\text { (Kappa Index) }\end{array}$ & $\begin{array}{l}\text { صحت طبقهبندى كل } \\
\text { (Overall Kappa) }\end{array}$ & سال \\
\hline $0 / 19$ &.$/ 9 \mu$ & 1991 \\
\hline$\circ / M \Lambda$ & $0 / 94$ & $Y \circ \circ \Lambda$ \\
\hline ०/^G & $\circ / 9 \mu$ & Y०|N \\
\hline
\end{tabular}

ش

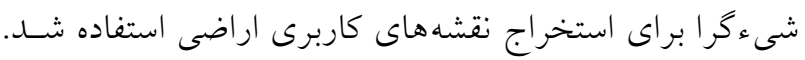

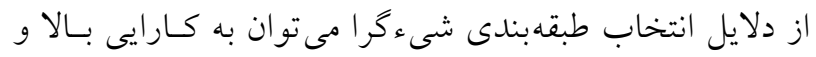

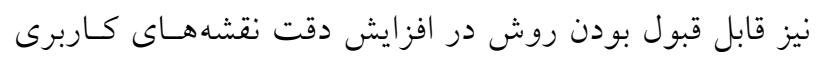

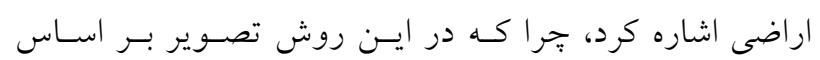

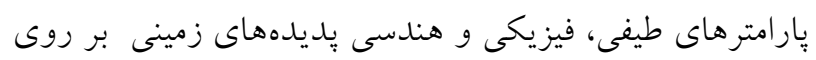

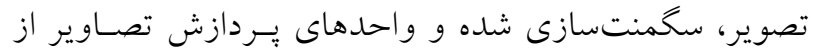

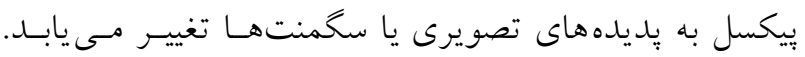

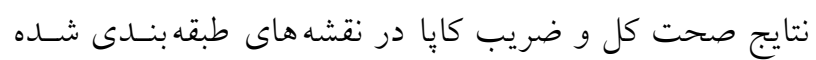

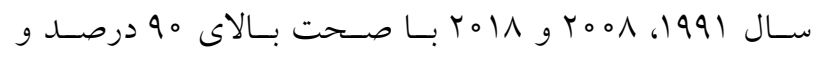

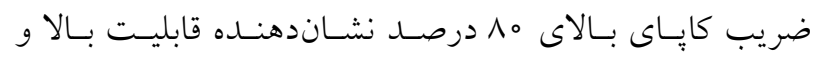

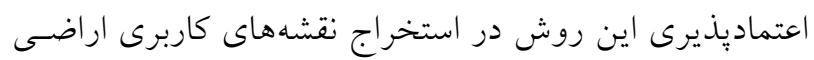

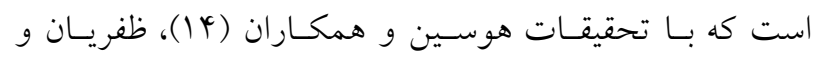

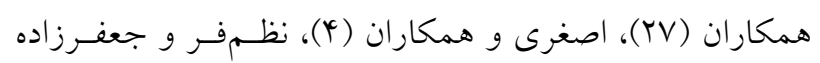

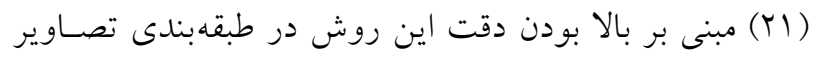

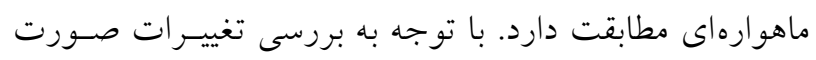

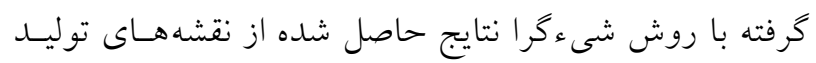

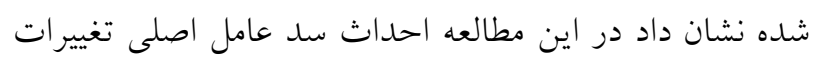

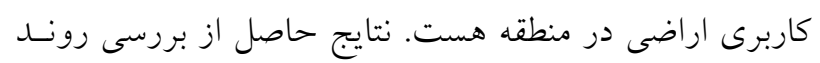

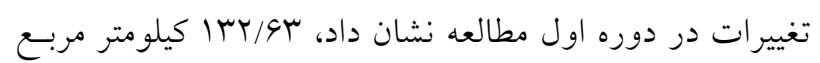

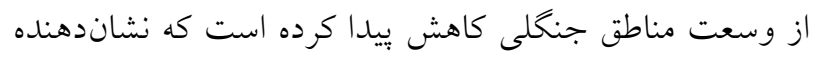

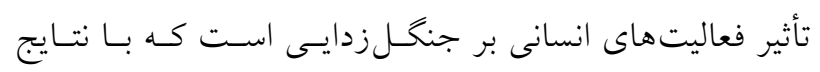

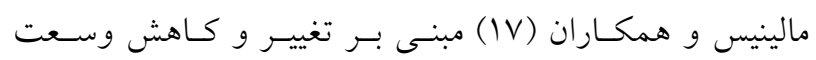

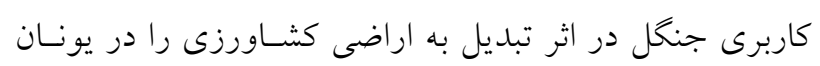

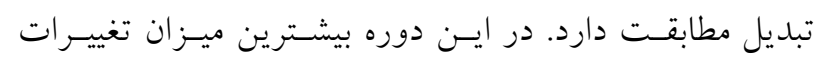

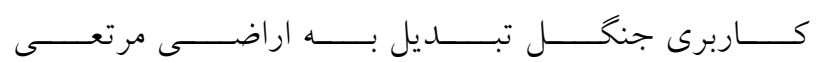

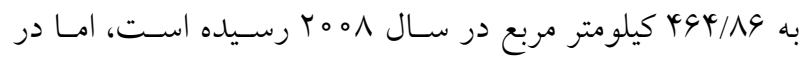

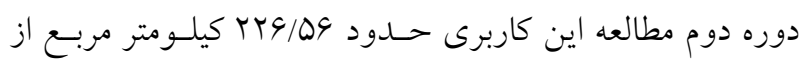

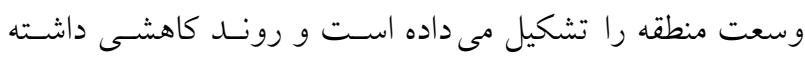

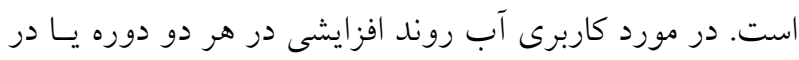

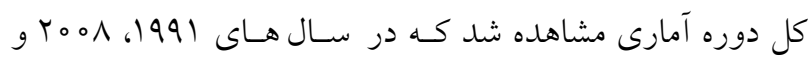

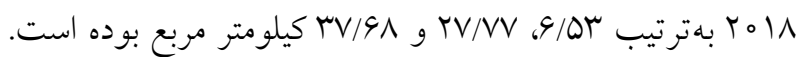

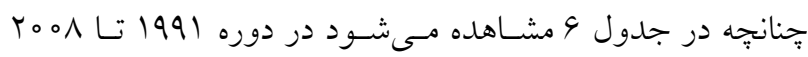

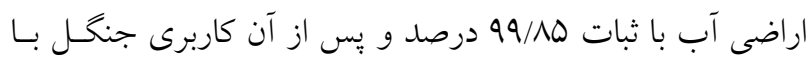

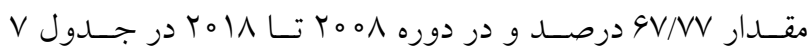

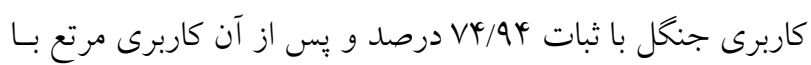

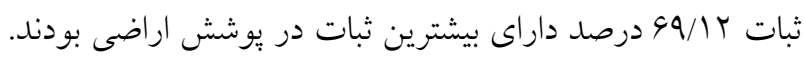
بررسى نتايج صحت نقشهاى طبقهبندى شده با روش شىءكرا

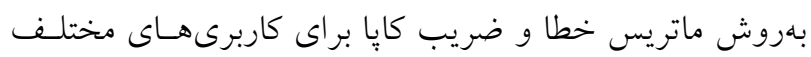

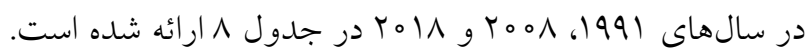

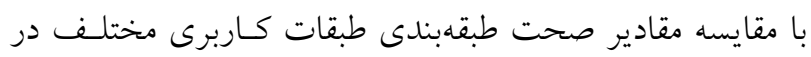

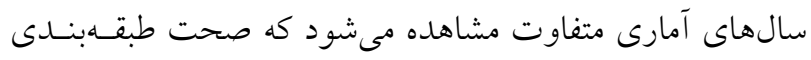

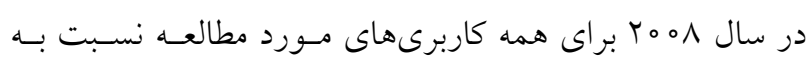

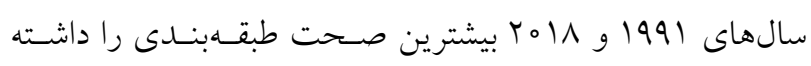

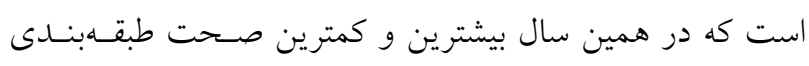

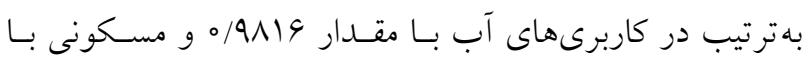

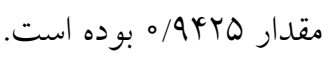

\section{بحث و نتيجه گيرى}

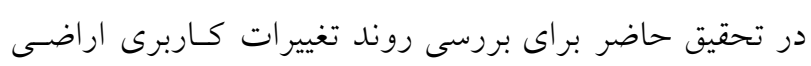

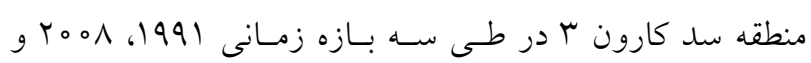




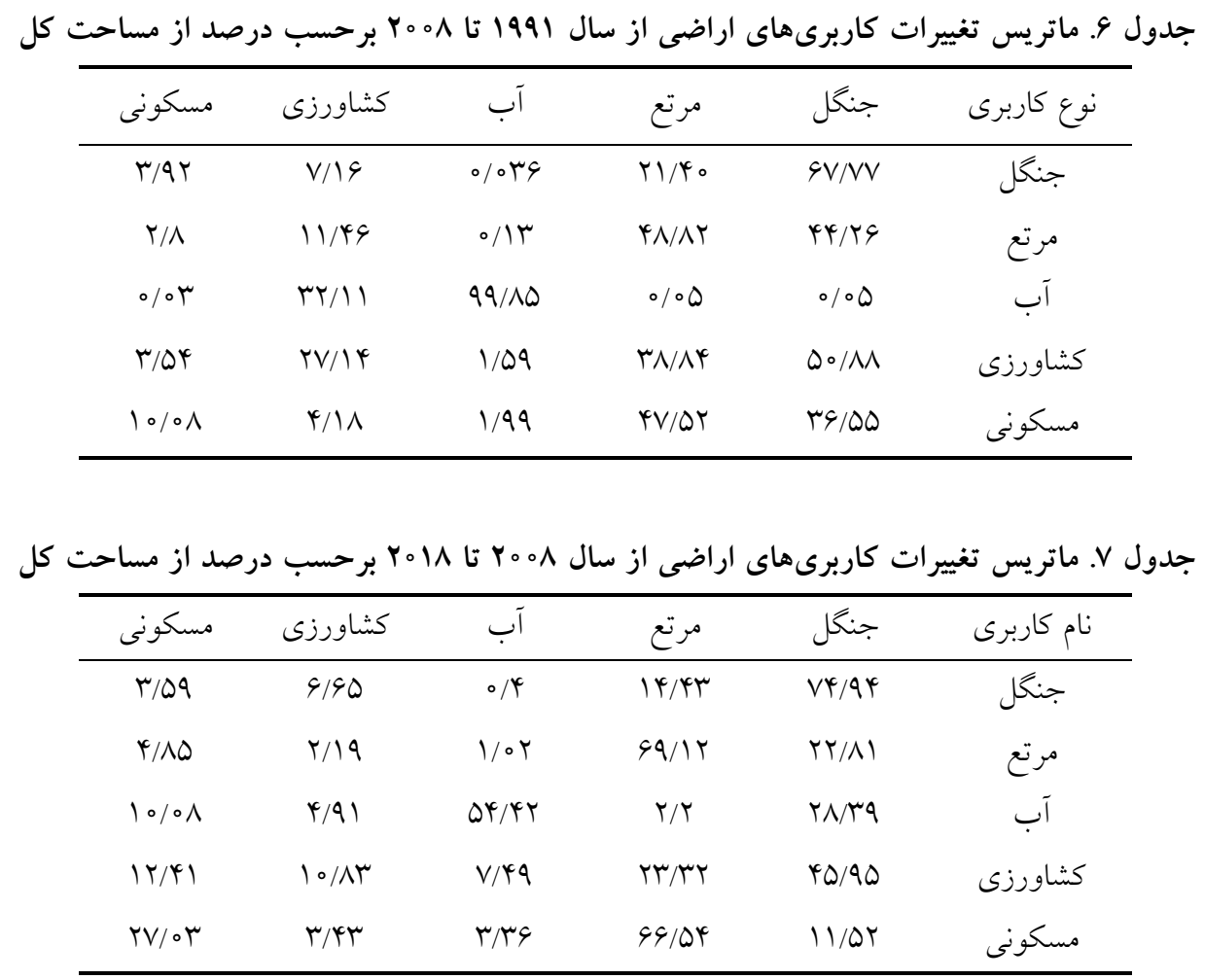

جدول ^. نتايج صحت طبقهبندى شىءگرا در كاربرىهاى مورد مطالعه

\begin{tabular}{|c|c|c|c|}
\hline سال ب.11 & سحت طبقهبن ^ه & سال 1991 & طبقات كاربرى اراضى \\
\hline ./9MाT & $. / 94+4$ & o/QMTEV & جنشل \\
\hline - /9Yor & $\circ / 90 \mathrm{VV}$ & - MYTY & مرتع \\
\hline$. / 91 / 4$ &.$/ 9119$ & - /9TGY & آب \\
\hline ./9MTI &.$/ 9494$ & - /QYYA & اراضى كشاورزى \\
\hline - /9MUV & - AYYQ & $\circ / 940$. & مسكونى \\
\hline ०/9MN &.$/ 94 \wedge F$ & $\circ / 9 M V T$ & صحت طبقهبندى كل \\
\hline ०/AGT. & -MNTG & ०/^91Y & ضريب كاياى كل \\
\hline
\end{tabular}

مشخص شد كه در سالهاى 1991-Yoه وجود منبع آب دائمى در منطقه ابتدا باعث شخم زدن منـاطق مرتعى و تبـديل آنهـا بـه

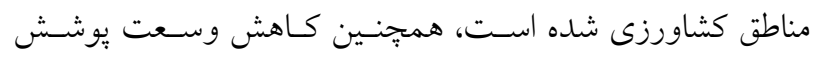

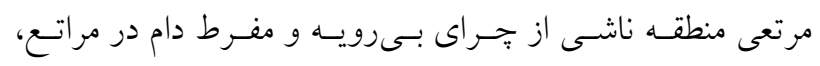

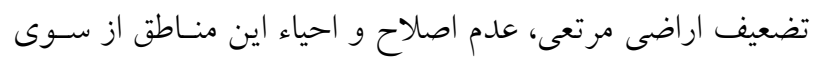
بهرهبرداران و دامداران، كاهش بارندگى و توسعه سـاختوسـازها

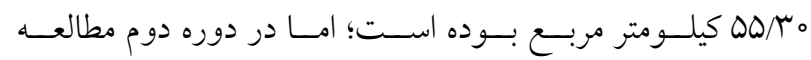

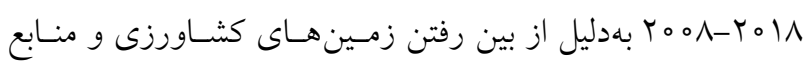
تغذيه، افـزايش هزينـه خـانوار، از دسـت دادن مالكيـت زمسين و كـاهش جمعيـت و مهـاجرت اجبـارى مـردم، دسـتانــازى بـــ

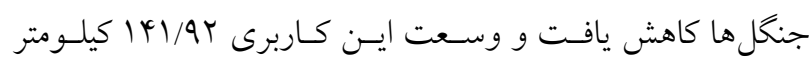
مربع روند افزايشى در بيش كرفت. بر اساس نتـايج ايسن مطالعـه 
حاضر رشد اراضى كشاورزى در دوره اول سب/\%ب كيلـومتر مربـع

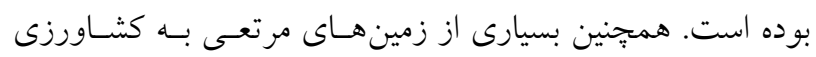

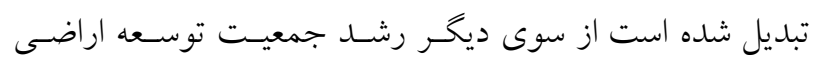

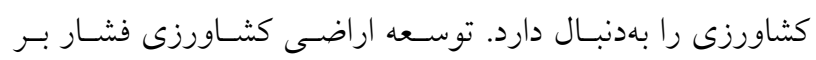

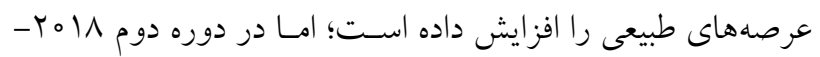

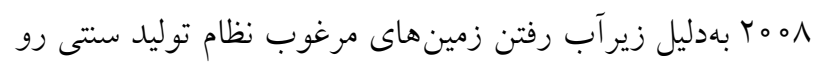

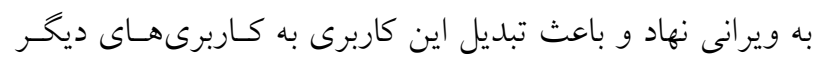

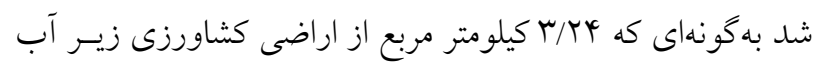

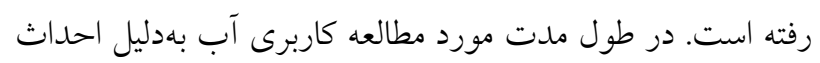

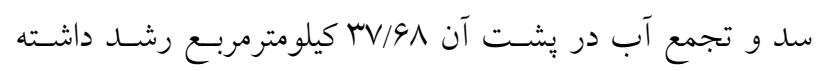

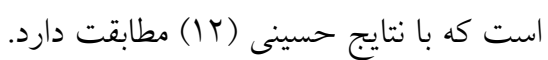

\section{نتيجه گيرى كلى}

در اين مطالعـه تغييـرات سـطح يوشـش و كـاربرى اراضسى در دو

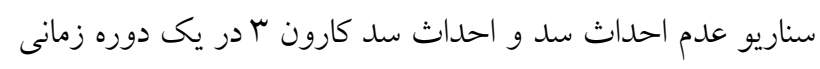

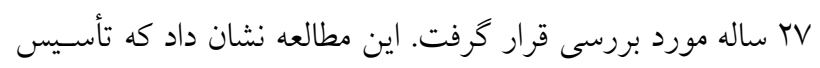

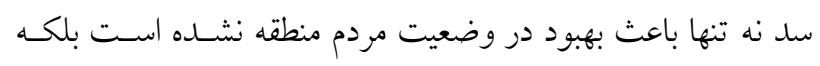

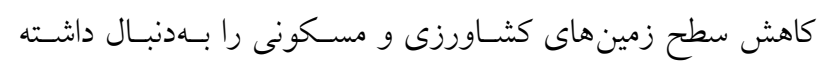

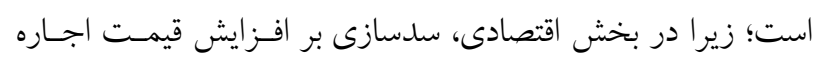

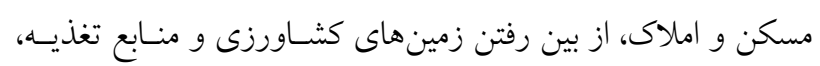

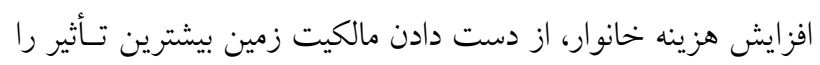

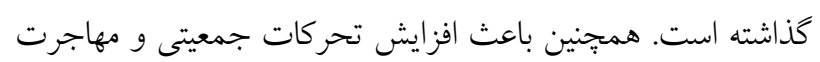

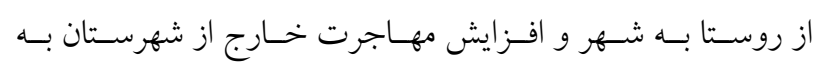

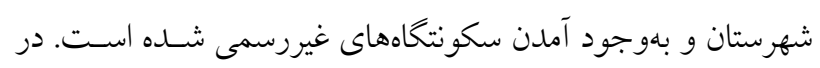

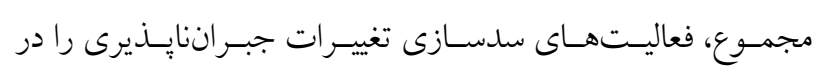

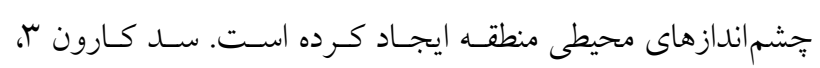

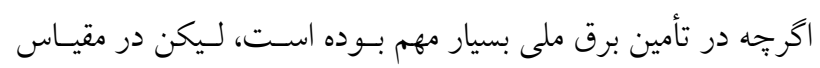

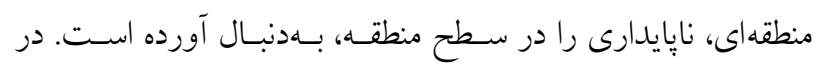

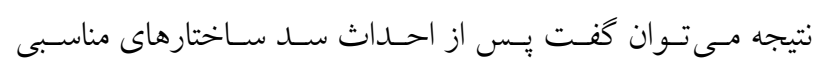

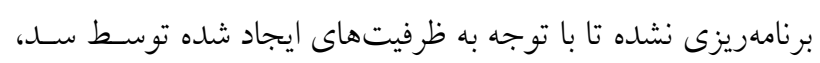
بتوان به بايدارى روستاها كمك كند.
هست كه با تحقيقات فارسى و يوسـفى (^) مطابقـت دارد. طبـق

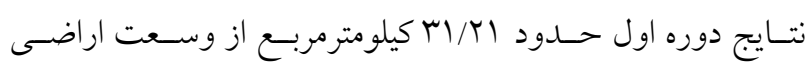

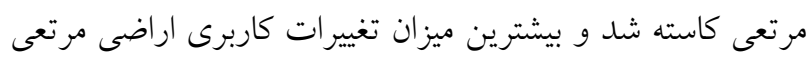

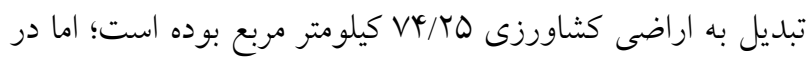

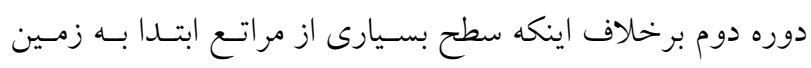

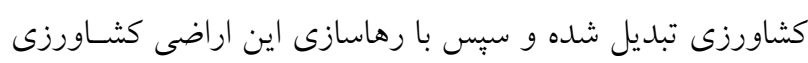

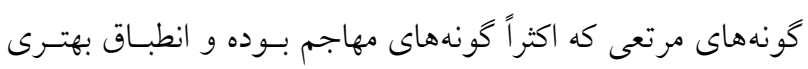

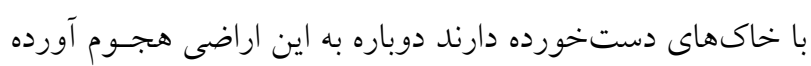

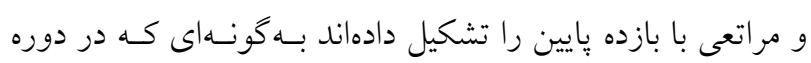

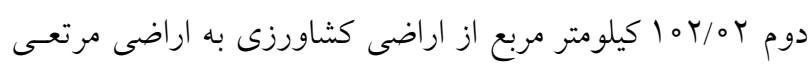

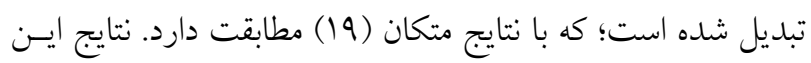

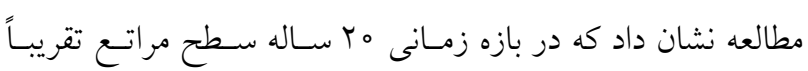

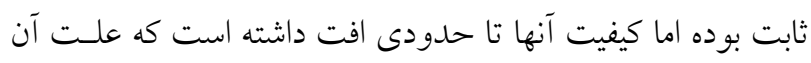

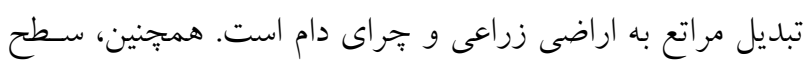

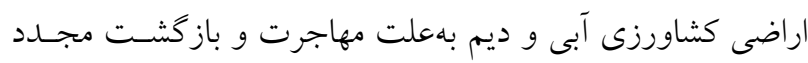

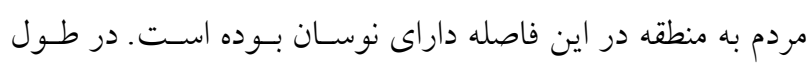

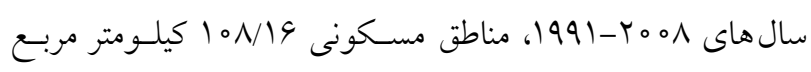

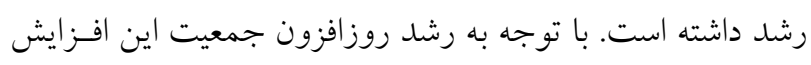

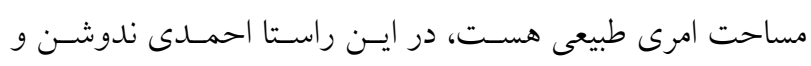

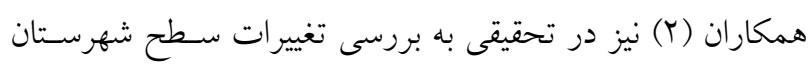

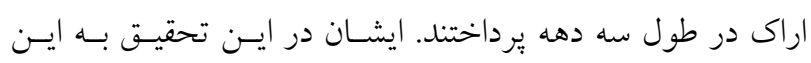

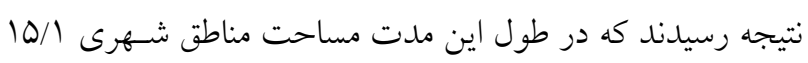

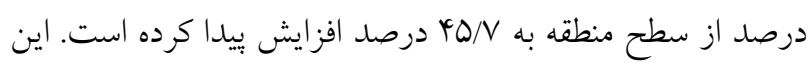

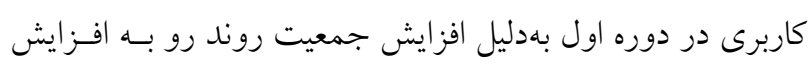

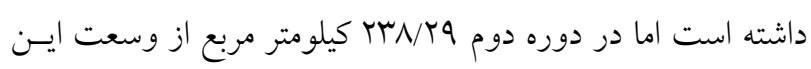

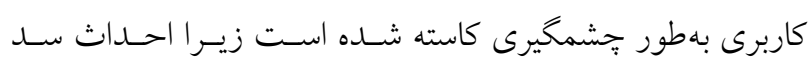

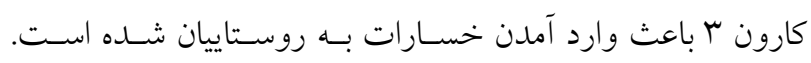

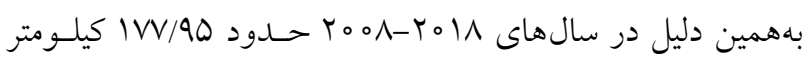

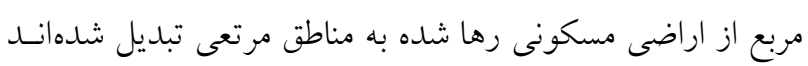

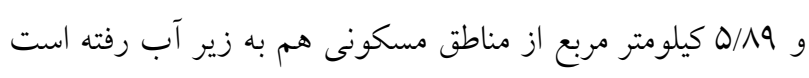

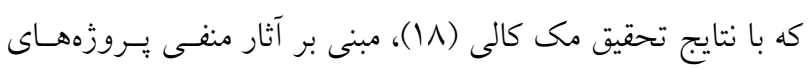

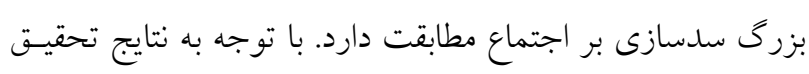


1. Arji, A. 1999. Land Use; Translated by M. Tabibian; Tehran: University of Tehran Press.

2. Ahmadi Nodooshan, M., A. Sufyanian and S. J. Khajehuddin. 2009. Preparation of city land cover map Arak using artificial neural network classification methods and maximum probability. Research Natural Geography 69: 83-98.

3. Arekhi, S., P. Gerayi and M. Arekhi. 2008. Evaluation of land use change process in Kabir Kouh protected area using RS and GIS. (Case study: Ilam province), Geomatics Conference 87, Tehran, Mapping Organization of Iran.

4. Asghari, P., H. Emami and V. Mohammadnejad. 2018. Investigation of land use changes using basic and objectoriented pixel methods and analysis of the effects of land use change on soil erosion (Case study: Maragheh city). Quantitative Geomorphology Research 8(29): 160-178.

5. Baatz, M. and A. Schape. 1999. Object-oriented and multi-scale image analysis in semantic network, in Proccedings 2nd International Symposium on Operalization of Remote Sensing, Ensched, ITC.

6. Blaschke, T. 2006. Object based image analysis for remote sensing. ISPRS Journal of Photogrammetry and Remote Sensing 65(1): 2-16.

7. Butt, A., R. Shabbir, S. Saeed Ahmad and N. Aziz. 2015. Land use change mapping and analysis using remote sensing and GIS: A case study of Simly watershed, Islamabad, Pakistan. The Egyptian Journal of Remote Sensing and Space Sciences 18: 251-259.

8. Farsi, J. and M. Yousefi. 2013. Detection of land use changes using remote sensing data (Case study: Bojnourd plain). Quarterly Journal of Geography and Environmental Information (7): 95 -116.

9. Feizizadeh, B. and A. Rasuli. 2007. Comparison of pixel based and objects - Oriented methods in providing land use maps case study: eastern plain of Uremia Lake, M.Sc. thesis, Remote Sensing and GIS Centrum of University of Tabriz. Tabriz. Iran.

10. Feizizadeh, B., A. Zand Karimi, M. Pirnazr and H. Abedi gheshlaghi. 2015. Assessing the use fuzzy algorithms in increasing the accuracy of land use maps by object-oriented processing methods. Geographical Data 24: 1-8. (In Farsi).

11. Hadian, F., R. Jafari, H. Bashari and N. Ramezani. 2013. Investigation of the effects of henna dam on changes in the level of cultivation and land use. Applied Ecology 2(4): 113-101.

12. Hoseini, H. 2015. Land use changes modeling Sari County using Artifical Neural Network, Thesis Submitted in Partial Fulfillment of the Requirements for the Degree of Master of Science (M.Sc).

13. Huang, L. and L. Ni. 2008. Object-oriented classification of high-resolution satellite image for better accuracy. Proceedings of the 8th International Symposium on Spatial Accuracy Assessment in Natural Resources and Environmental Sciences, Shanghai, P. R. China, June 25(27): 211-218.

14. Hussain, M., D. Chen, A. Cheng, H. Wei and D. Stanley. 2013. Change detection from remotely sensed images: From pixel-based to object-based approaches. ISPRS Journal of Photogrammetry and Remote Sensing 80: 91-106.

15. Jiang, X., D. Lu, E. Moran, M. F. Calvi, L. V. Dutra and G. Li. 2018. Examining impacts of the Belo Monte hydroelectric dam construction on land-cover changes using multitemporal Landsat imagery. Journal of Geography 97: 35-47.

16. Kianisalmi, E. and A. Ebrahimi. 2018. Evaluation of change detection and future condition of meadow-land ecosystem of Shahrekord using landsat data. Journal of Range and Watershed Managment 71(2): 473-484. (In Farsi).

17. Mallinis, G., I. Z. Gitas, V. Giannakopoulos, F. Maris and M. TsakiriStrati. 2011. An object-based approach for flood area delineation in a transboundary area using ENVISAT ASAR and LANDSAT TM data. International Journal of Digital Earth 6(2): 124 -136.

18. McCully, P. 1996. Excerpt from Silenced Rivers: The Ecologe and Politics of Large Dams. Zed Books, London.

19. Motkan, A., Kh. Saeedi, A. S. Shakiba and A. Hosseini ASL. 2010. Evaluation of land cover changes in relation to Taleghan Dam using remote sensing techniques. Journal of Applied Research in Geographical Sciences 16(19): 6445.

20. Nazmfar, H. and J. Jafarzadeh. 2017. Investigating the efficiency of satellite image classification methods in evaluating land use change changes using scale optimization in object-oriented processing (Case: Ardabil city). Journal of Urban Research and Planning 10(36): 117-128.

21. Parvar, Z., K. Shaysteh, M. Behzadfar and N. Azizkhani Shadisheh. 2016. Detection of changes resulting from construction of Shirin Darreh dam on land use/land cover in Downstream Basin. Environmental Research 7(41): 202-191.

22. Rafiyan, A., A. DervishSefat, S. Babaie and A. Metaji. 2010. Evaluation of pixel classifications and ground base aerial images for tree species (Case study: Chamestan Nour forestry). Forest Journal of Iran, Iranian Forestry Association 3(1): 35-47. 
23. Saber Haghighat, A. 2008. Investigating the effects of land use change on erosion and sediment in golestan river basin watershed. Master Thesis in Geography, Faculty of Literature and Human Sciences, Ferdowsi University of Mashhad. (In Farsi).

24. Taze, M. and N. Khalili Samani. 2013. Study of land use change changes in Shahrekord county using remote sensing technique (1976 to 2055). First National Conference on the Environment, Energy and Biological Defense, Tehran, Mehr Arvand Higher Education Institution, Promotion Group for Environmental Lovers.

25. Wang, Z., W. Wei, S. Zhao and X. Chen. 2004. Object-oriented classification and application in land use classification using SPOT-5 PAN imagery. In Geoscience and Remote Sensing Symposium, 5: 3158-3160.

26. Yan, G. J., F. Mas, B. H. P. Maathuis, Z .Xiangmin and P. M. V. Dijk. 2006. Comparison of pixel-based and object-oriented image classification approaches-a case studyin a coal fire area, Wuda, Inner Mongolia, China. International Journal of Remote Sensing 27: 4039-4055.

27. Zafarian, E., A. Ebrahimi and R. Omidipour. 2018. Evaluation of the efficiency of satellite imagery classification approaches in monitoring of land cover changes (Case study: Shahrekord basin, Chaharmahal and Bakhtiari). Journal of Range and Watershed Managment 71(3): 699-714. (In Farsi).

28. Zhao, Q., S. Liu, L. Deng, S. Dong, Y. Zhang and Q. Liu. 2013. Determining the influencing distance of dam construction and reservoir impoundment on land use: A case study of Manwan Dam, Lancang River. Journal of Ecological Engineering 53: 235-242. 


\title{
Assessing the Trend of Spatial Land Use Changes of Karun 3 Dam in the Period 1991 to 2018
}

\author{
M. Pajoohesh ${ }^{1 *}$, H. Shekoohideh ${ }^{1}$ and Z. Heidari Ghahfarrokhi ${ }^{2}$
}

(Received: August 4-2020; Accepted: February 27-2021)

\begin{abstract}
Land use changes identifying to assess and monitor sensitive areas for sustainable planning and land management is essential. Remote sensing and the use of GIS technology as some of the most common methods in the world in monitoring land changes, especially, in the study of large areas. In this study, the trend of spatial land use changes in the area of Karun 3 dam was investigated. in the before and after the construction periods and dam intake using remote sensing and GIS over 27 years. In this study, the satellite imagery of Landsat 5 TM sensors from 1991 and 2008 and Landsat 8 OLI sensors in 2018 were analyzed and processed. Using object-oriented classification with land use maps for the three periods 1991, 2008, and 2018 with the overall accuracy of the Kappa index of 0.93 and 0.89 percent for 1991, 0.94, and 0.88 percent in 2008 and 0.93 , respectively, and $0.86 \%$ in 2018 was prepared. The results showed that the water use of the region with an area of 37.68 square kilometers is increasing and agricultural lands and residential areas with an area of 1349.04 and 226.56, respectively, forest lands with an area of 1041.49 remained as the dominant cover of the region and rangelands by going through a decreasing trend of increase in both periods after forest use, with an area of 878.87, they had the largest area. According to the obtained results, it can be said that the construction of the Karun 3 dam has caused the flooding of agricultural lands and their conversion to another use, as a result of which the villagers were forced to migrate due to losing their jobs and abandoned residential areas become other uses.
\end{abstract}

Keywords: Karun 3 dam, Satellite images, Object-oriented classification, Land use changes

1. Department of Soil and Water Conservation, Faculty of Natural Resources and Earth Science, Shahrekord University, Chaharmahal-Va-Bakhtiari, Iran.

2. Department of Range Management, Faculty of Natural Resources and Earth Science, Shahrekord University, Chaharmahal-Va-Bakhtiari, Iran.

Corresponding author, Email: drpajoohesh@gmail.com 